\title{
Koridor Jl. R.E. Martadinata ditinjau dari Kelengkapan Elemen, Ukuran, Peletakan dan Material Jalur Pedestrian
}

\author{
Irfan Sabarilah Hasim, Annisa Tresna Budi, Dearesti Ozadita Prabandani, Rika \\ Amalia Suhendro
}

\author{
Jurusan Arsitektur, Fakultas Teknik Sipil dan Perencanaan, Itenas, Bandung
}

Email : ishasim@itenas.ac.id

\begin{abstract}
ABSTRAK
Jalur pedestrian merupakan salah satu elemen dari kota yang sangat penting dalam menunjang aktifitas perkotaan yang sehat dan berkelanjutan. Banyak jalur pedestrian pada jalan-jalan utama Kota Bandung sedang diperbaiki, salah satunya adalah jalur pedestrian di Jl. R.E.Martadinata. Sebagai sebuah ruang publik, jalur pedestrian Jl. R.E. Martadinata harus bisa diakses oleh semua kalangan dengan baik dan aman. Jalur pedestrian yang baik harus mempunyai elemen-elemen yang baik dan menunjang aktifitas pejalan dan rancanganya harus sesuai dengan standar-standar yang berlaku. Penelitian ini bertujuan untuk menganalisis rancangan pedestrian berdasarkan kelengkapan elemen, standar ukuran, peletakan dan jenis material melalui metode survey dan studi pustaka. Metode survey digunakan untuk mengamati dan mengukur obyek penelitian sementara studi pustaka untuk mencari teori yang sesuai yang akan digunakan untuk mengkaji obyek penelitian. Dari hasil penelitian dapat disimpulkan bahwa Koridor Jl. R.E. Martadinata sudah memiliki kelengkapan elemen material dan pendukung jalur pedestrian dan sebagian besar sudah memenuhi standar, ukuran, peletakan dan jenis material yang dikeluarkan oleh Pemerintah.
\end{abstract}

Kata Kunci :Jalur Pedestrian, Koridor, Jalan, R.E.Martadinata

\section{ABSTRACT}

The Pedestrian path is one of the most important elements of the city in supporting healthy and sustainable urban activities. Many pedestrian paths on the main streets of the city of Bandung were being improved; one of them is on Jl. R.E.Martadinata. As a public space, pedestrian path on Jl. R.E.Martadinata should be accessible by all people properly and safely. Pedestrian paths that must be possessed by good elements and support pedestrian activities and design must be in accordance with applicable standards. This study aims to analyze the design of pedestrians based on the completeness of elements, standard sizes, laying and type of material through survey methods and literature studies. The survey method used to examine and measure research objects while library library to find the appropriate theory that will be used to study the research object. From the research results it can be concluded that the Corridor Jl. BACK. Martadinata already has complete elements of material and supporting pedestrian paths and most have met the standards, sizes, laying and types of materials issued by the Government.

Keywords : The Pedestrian Path, Corridor, Street, R.E.Martadinata 


\section{PENDAHULUAN}

Jalur pedestrian merupakan salah satu elemen dari kota yang sangat penting dalam menunjang aktifitas perkotaan yang sehat dan berkelanjutan. Banyak jalur pedestrian pada jalan-jalan utama Kota Bandung sedang diperbaiki, salah satunya adalah jalur pedestrian di Jl. R.E.Martadinata. Sebagai sebuah ruang publik, jalur pedestrian Jl. R.E. Martadinata harus bisa diakses oleh semua kalangan dengan baik dan aman. Ruang publik menurut Stephen Carr (1992) adalah ruang milik bersama, tempat masyarakat melakukan aktivitas fungsional dan ritual dalam suatu ikatan komunitas, baik kehidupan sehari-hari maupun dalam perayaan berkala[1]. Sementara menurut Carmona (2008) dalam Johannes (2012) Ruang Publik harus dapat diakses oleh siapa saja dan menjamin kebebasan dalam beraktivitas[2]. Berdasar dari kedua teori diatas maka dapat disimpulkan bahwa ruang publik adalah ruang milik bersama yang bisa diakses oleh siapa saja, anak kecil, dewasa, laki-laki, perempuan, orang sehat maupun orang berkebutuhan khusus, tanpa kecuali.

Pedestrian sebagai sebuah ruang publik tentu saja harus dapat diakses oleh siapa saja dan penggunanya harus dijamin keselamatannya dalam beraktivitas. Pedestrian yang aman dapat memberikan dampak positif bagi kota beserta aktivitasnya. Shirvani (1985) dalam Sukawi (2006) menyatakan jalur pejalan kaki (trotoar) merupakan elemen perancangan kota yang penting, yaitu membentuk keterhubungan antar aktivitas pada suatu lokasi. Jalur pejalan kaki merupakan subsistem linkage dari jalur suatu kota. Jalur pejalan kaki akan semakin penting bila pejalan kaki adalah sebagai pengguna utama jalur tersebut bukan kendaraan bermotor atau hal lainnya[3].

Berkaitan dengan rancangan pedestrian Peraturan Menteri Pekerjaan Umum Nomor: 03/PRT/M/2014 pasal 2 ayat 2 menyebutkan bahwa Peraturan Menteri dibuat dengan tujuan untuk mewujudkan jaringan pejalan kaki di kawasan perkotaan yang aman, nyaman, dan manusiawi sehingga mendorong masyarakat untuk berjalan kaki dan menggunakan transportasi publik. Ketentuan dan tata cara perencanaan, penyediaan, pemanfaatan prasarana dan sarana jaringan pejalan kaki terdapat didalam peraturan menteri tersebut diatas, sehingga semua perencanaan sudah seharusnya mengacu terhadap peraturan menteri tersebut.

Jalan R.E. Martadinata adalah jalan kolektor primer sepanjang $2.93 \mathrm{~km}$ yang menghubungkan Jalan Wastukencana dengan Jalan A. Yani. Beberapa fungsi dalam koridor meliputi, kantor pemerintahan, komersial dan pendidikan menjadikan salah satu koridor yang strategis di Kota Bandung. Lokasi ini dipilih menjadi objek penelitian karena lokasinya yang strategis dan sudah mengalami perbaikan. Tujuan dari penelitian ini untuk mengetahui kesesuaian rancangan dengan teori dan standar yang berlaku ditinjau dari aspek pejalan kaki (pedestrian).

\section{METODOLOGI}

\subsection{Lokasi dan Waktu Penelitian}

Penelitian dilaksanakan di pedestrian koridor Jl. R. E. Martadinata, Bandung Jawa Barat, sepanjang 2.93 Km. Penelitian dilakukan sejak bulan September 2016 sampai dengan Desember 2016.

\subsection{Metode Penelitian}

Penelitian menggunakan metode deskriptif kualitatif. Data dikumpulkan melalui metode survei dan studi pustaka. Menurut Sabar (2007) dalam Nooriman (2016), pengambilan data melalui metode survei dilakukan dengan menggunakan metode purposive sample, secara sengaja berdasarkan dengan sifat atau karakteristik penelitian. Sampel adalah sebagian dari objek dalam populasi yang diteliti, yang sudah tentu mampu dapat mewakili populasinya [4]. Studi pustaka dilakukan untuk membuat variabel penelitian yang akan digunakan untuk membuat analisa terhadap obyek penelitian. Analisa dilakukan 
dengan metode komparasi yaitu membandingkan rancangan pedestrian dengan teori-teori terkait dan standar yang dikeluarkan pemerintah dengan terlebih dahulu membuat variabel penelitian.

Studi pustaka yang pertama digunakan untuk menganalisa elemen-elemen yang harus dimiliki oleh jalur pedestrian menurut Teori Rubenstein. Menurut Rubenstein dalam Syoufa (2017), disebutkan bahwa jalur pedestrian seharusnya mempunyai elemen-elemen sebagai berikut [5]:

1. Elemen jalur pedestrian sendiri (material jalur pedestrian). Elemen-elemen material yang umum digunakan adalah paving (beton), bata atau batu.

2. Elemen pendukung pada jalur pedestrian antara lain:

a. Lampu, yang digunakan sebagai penerangan di waktu malam untuk meningkatkan keamanan jalan dan keamanan terhadap ancaman kejahatan.

b. Sign, merupakan rambu yang sifatnya memberikan identitas, informasi maupun larangan

c. Sculpture, dibuat untuk mempercantik jalur pedestrian dan menarik perhatian mata (vocal point)

d. Bollard, adalah pembatas antara jalur pedestrian dengan jalur kendaraan.

e. Bangku, untuk memberi ruang istirahat bila lelah berjalan.

f. Tanaman Peneduh, untuk perlindungan dan penyejuk pedestrian.

g. Telepon, biasanya disediakan bagi pedestrian jika ingin berkomunikasi

h. Kios/ shelter dan kanopi, keberadaannya dapat menghidupkan suasana pada jalur pedestrian sehingga tidak monoton.

Studi pustaka berikutnya digunakan untuk menganalisa kesesuaian rancangan dengan standar yang dikeluarkan oleh. Untuk mengetahui apakah pedestrian sudah memenuhi standar perencanaan maka dibuatlah variabel penelitian berdasarkan Peraturan Menteri Pekerjaan Umum sebagai berikut:

1) Sirkulasi, meliputi lebar minimum pedestrian normal $0.9 \mathrm{~m}$, dan $1.5 \mathrm{~m}$ untuk bisa digunakan oleh difabel, kelandaian dibawah $8 \%$, tinggi maksimal $20 \mathrm{~cm}$ dari jalan, ukuran ubin pengarah $30 \times 30$ dan jenis material standar beton cetak.

2) Lampu Pedestrian, tinggi $4 \mathrm{~m}$, jarak peletakan setiap $10 \mathrm{~m}$ dan material yang disarankan metal dan beton cetak.

3) Rambu jalan diletakan di titik interaksi sosial pedestrian jalur padat dan material tidak menimbulkan efek silau

4) Penyeberangan/ Zebra Cross, lebar $0.3 \mathrm{~m}$, panjang minimal $2.5 \mathrm{~m}$, celah garis $0.3 \mathrm{~m} \mathrm{~s} / \mathrm{d} 0.6 \mathrm{~m}$ dan peletakan di tiap simpang.

5) Tempat Duduk, lebar $0.4 \mathrm{~m}$ s/d $0.5 \mathrm{~m}$, jarak setiap $10 \mathrm{~m}$, dan material yang dianjurkan metal atau beton cetak

6) Tempat Sampah, jarak setiap 20m dan material yang dianjurkan metal dan beton cetak.

7) Halte, lapak tunggu radius $300 \mathrm{~m}$ dan material yang dianjurkan metal dan beton.

8) Vegetasi peneduh, percabangan minimal $2 \mathrm{~m}$ dari tanah dan jenis yang dianjurkan Kiara Payung, Tanjung, Bungur, Mahoni, Angsana, Akasia, Bogenvil dan Teh-tehan.

\section{HASIL DAN PEMBAHASAN}

Ruang yang disurvey dan dikaji adalah Koridor Jalan R.E Martadinata Bandung, dari simpang yang yang berbatasan dengan Jl. Wastukencana sampai dengan simpang Jl Ahmad Yani sepanjang 2,93 km (gambar 3.1 Peta situasi Koridor Jl. R.E. Martadinata). 


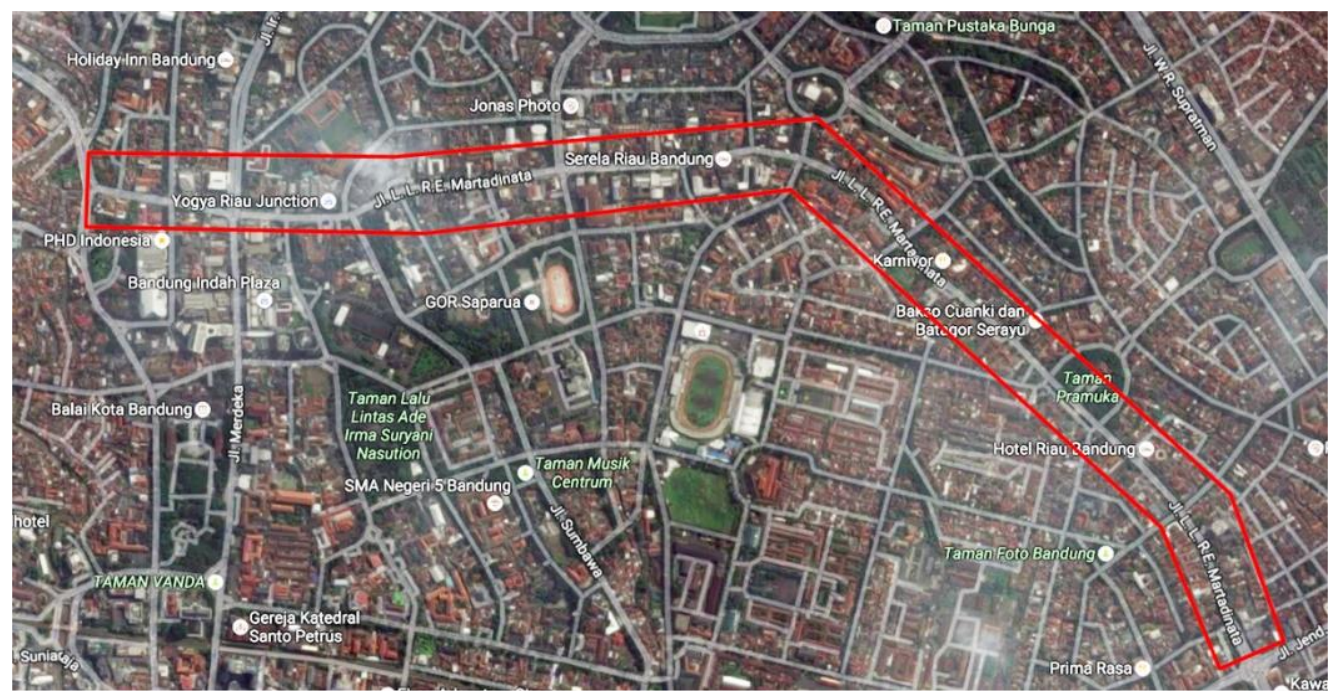

Gambar 3.1. Peta Situasi Koridor Jl. R.E. Martadinata

Untuk memudahkan dalam proses analisa maka kajian dibagi kedalam 8 segmen dengan kriteria pembagian segmen berdasarkan karakteristik persimpangan besar yang ada lampu lalu lintasnya (persimpangan yang mempunyai lampu merah). Adapun 8 segmen tersebut sebagai berikut: 1) Segmen 1, antara Jl. Wastukencana sampai dengan Jl. Merdeka, 2) Segmen 2, antara Jl. Merdeka sampai dengan Jl. Trunojoyo, 3) Segmen 3, antara Jl. Trunojoyo sampai dengan Jl. Banda, 4) Segmen 4, antara Jl. Banda sampai dengan Jl. Lombok, 5) Segmen 5, antara Jl. Lombok sampai dengan Jl. Cihapit, 6) Segmen 6, antara Jl. Cihapit sampai dengan Jl. Taman Pramuka, 7) Segmen 7, antara Jl. Taman Pramuka sampai dengan Jl. Anggrek, 8) Segmen 8, antara Jl. Anggrek sampai dengan Jl. A. Yani. (Gambar 2).

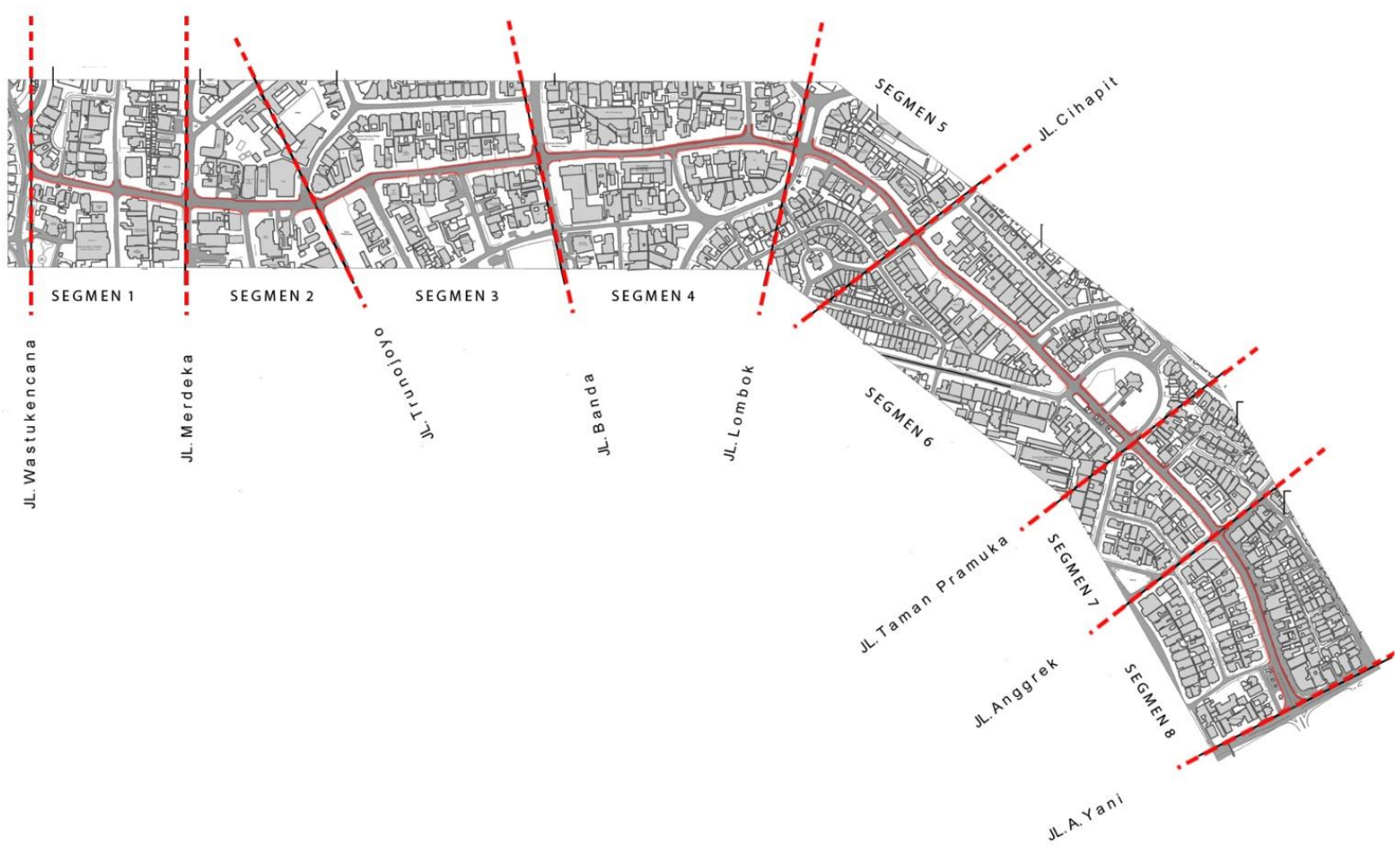

Gambar 3.2. Pembagian Segmen Koridor Jl. R.E. Martadinata 


\subsection{Elemen-elemen Jalur Pedestrian}

Pada tahap pengumpulan data, semua data direkam, didokumentasikan dan diukur. Berdasarkan hasil survey dihasilkan data-data sebagai berikut :

1. Pedestrian mempunyai ukuran yang berbeda-beda di setiap segmen (gambar 3), dengan lebar rata-rata antara $2.5 \mathrm{~m}-6 \mathrm{~m}$. Beberapa tempat ada yang lebih kecil dari $1 \mathrm{~m}$. Tinggi pedestrian dari jalur kendaraan $15 \mathrm{~cm}$, dan ada sebagian kecil yang mempunyai tinggi $45 \mathrm{~cm}$. Material yang digunakan untuk pedestrian adalah batu granit bakar untuk ruang pejalan dan material beton cetak untuk ubin pengarah. (gambar 3.4).

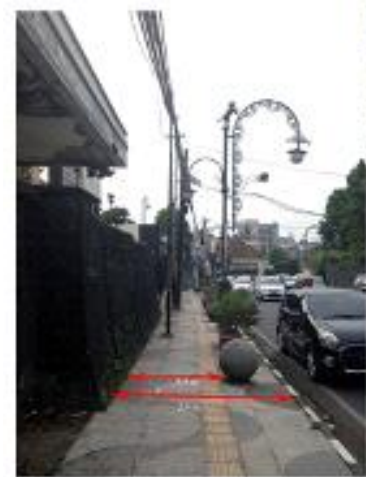

Lebar $2.4 \mathrm{~m}$

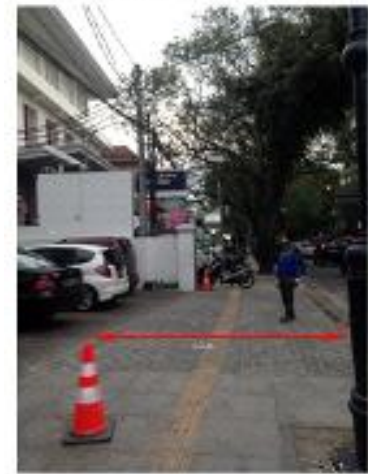

Lebar $4.0 \mathrm{~m}$

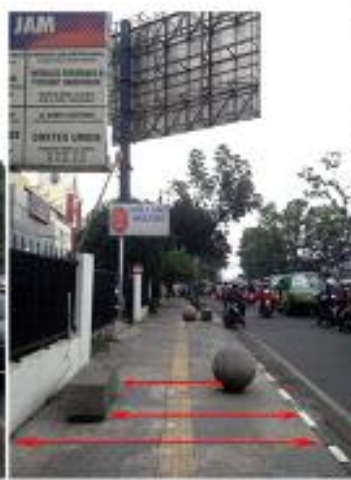

Lebar $3.0 \mathrm{~m}$

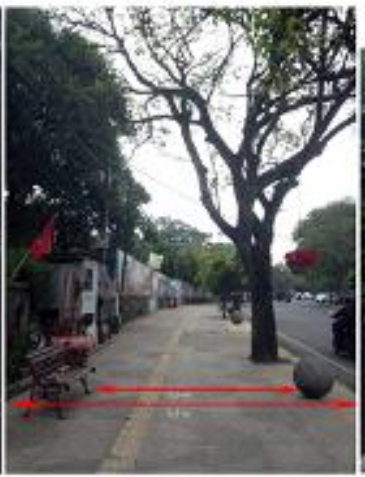

Lebar $5.1 \mathrm{~m}$

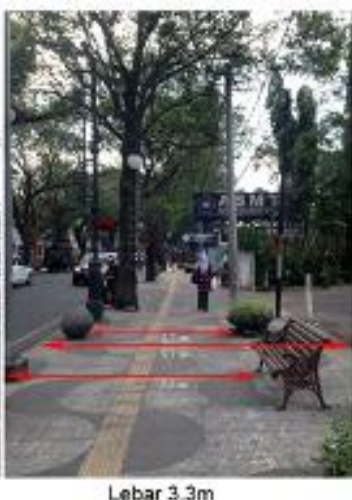

Lebar $33 \mathrm{~m}$

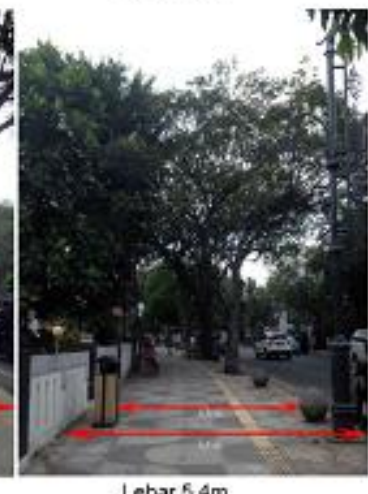

Lebar $5.4 \mathrm{~m}$

Gambar 3.3 Ukuran Lebar Pedestrian
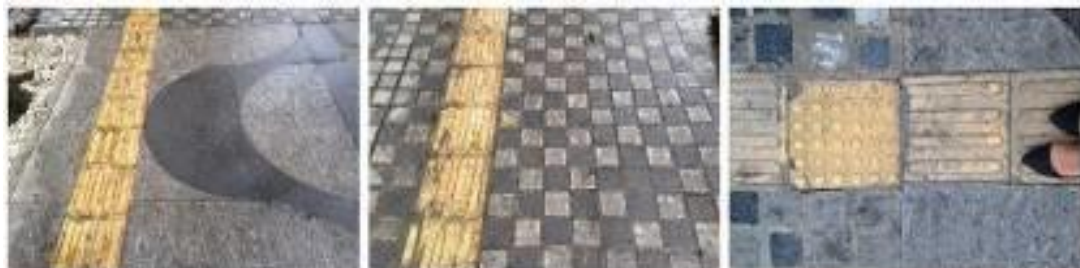

Gambar 3.4. Material Pedestrian

2. Desain dan ukuran lampu jalan mempunyai desain yang sama di keseluruhan segmen Mempunyai bentuk tiang tunggal dibawah, dan ganda di bagian atas dilengkapi lampu jalan dan lampu pejalan, dengan tinggi $\pm 4 \mathrm{~m}$ dan material metal. Terlihat bahwa lampu jalan baru dipasang di lokasi, sehingga ada beberapa titik yang belum ada dan semua lampu belum menyala (Tabel 1 nomor 1)

3. Rambu jalan yang terdapat di lokasi penelitian termasuk jenis rambu kecil dengan ketinggian \pm $3 \mathrm{~m}$ dan material metal. (Tabel 1 nomor 2)

4. Penyeberangan jalan (zebra cross), terdapat di semua persimpangan garis putih yang dicat di atas aspal dengan ukuran garis lebar $0.3 \mathrm{~m}$, panjang $2.5 \mathrm{~m}$ dan jarak antar garis (celah) selebar $0.3 \mathrm{~m}$. (Tabel 1 nomor 3)

5. Tempat duduk tersebar di lokasi penelitian mempunyai ukuran lebar $0.33 \mathrm{~m}$, panjang $1.4 \mathrm{~m}$ dan tinggi $0.4 \mathrm{~m}$. Jarak antar tempat duduk ada yang $6.6 \mathrm{~m}$ dan ada yang sampai $12 \mathrm{~m}$. Tempat duduk 
terlihat baru dipasang dan di beberapa segmen (segmen 7 dan 8) belum terdapat tempat duduk. Material yang digunakan adalah besi cor dan kayu. (Tabel 1 nomor 4)

6. Tempat sampah tersebar di lokasi penelitian dengan jarak antara $10 \mathrm{~m}$ sampai dengan $40 \mathrm{~m}$. Terdapat dua jenis tempat sampah dengan material yang berbeda, satu menggunakan besi dengan plastik, satu lagi menggunakan material besi dengan kayu (gambar 9). Beberapa segmen (segmen 7 dan 8) belum mempunyai tempat sampah. (Tabel 1 nomor 5)

7. Halte terdapat di beberapa segmen (segmen 1,2 dan 5) dibangun dengan material pasangan bata dan beton, dengan penyelesaian ACP dan keramik. (Tabel 1 nomor 6)

8. Vegetasi peneduh ditanam berbaris di lokasi penelitian, mempunyai tinggi rata-rata diatas $10 \mathrm{~m}$ dengan percabangan diatas $2.5 \mathrm{~m}$. Jenis berbeda-beda di setiap segmen, yaitu; angsana, mahoni dan tanjung. (Tabel 1 nomor 7)

Tabel 1. Kelengkapan Perkakas Koridor Jl. R.E. Martadinata

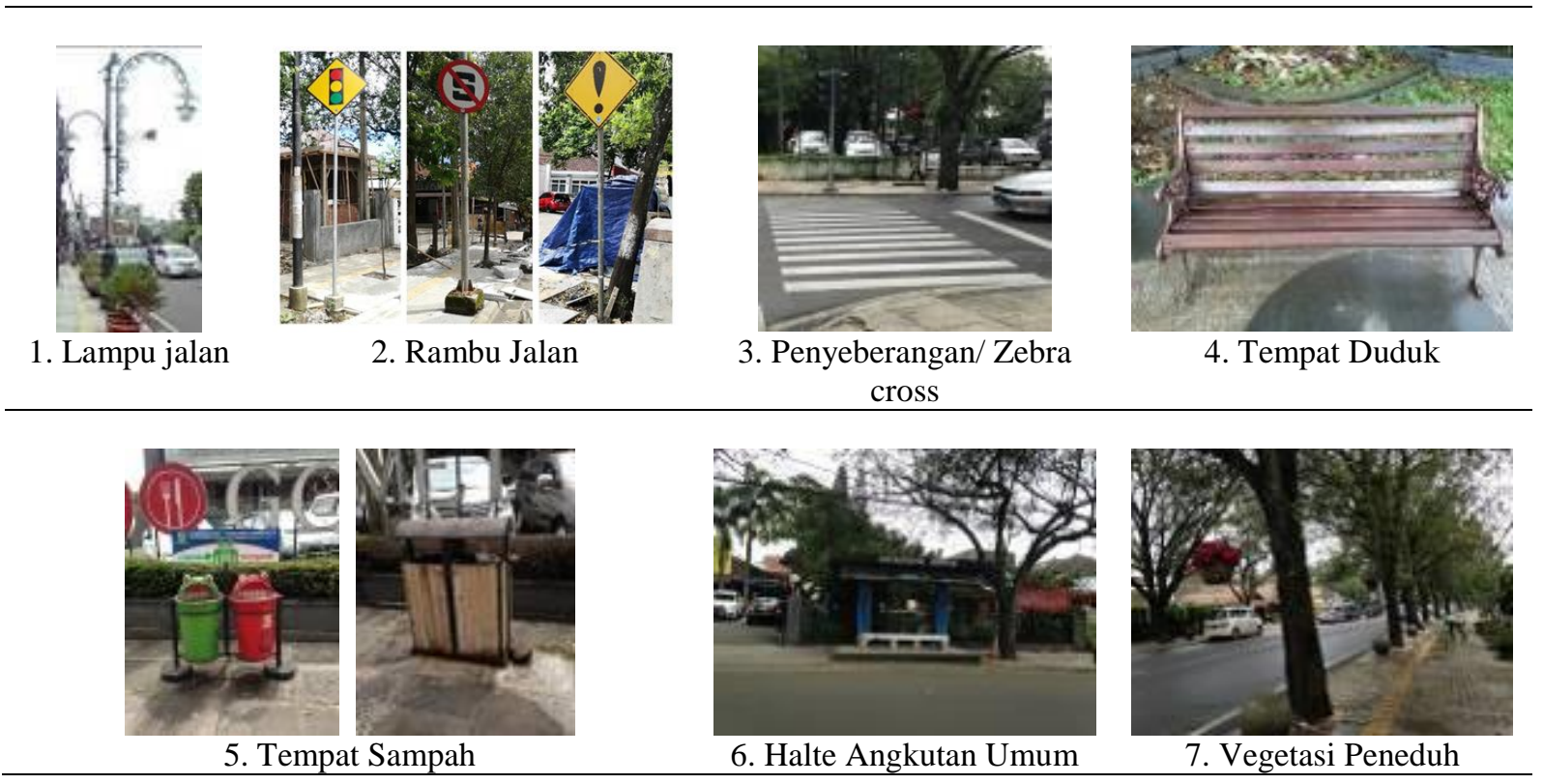

\subsection{Ukuran, peletakan dan material elemen-elemen pedestrian}

Untuk memudahkan analisa, hasil pengukuran juga ditampilkan dalam profil potongan jalan di setiap segmen. (Tabel 2. Potongan Jalan tiap Segmen)

Tabel 2. Potongan Jalan tiap Segmen

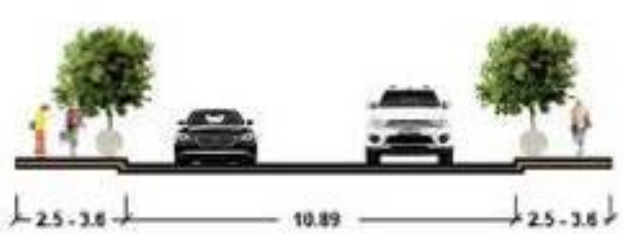

Potongan Jalan Segmen 1

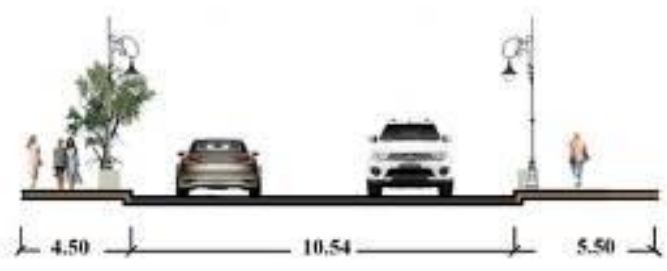

Potongan Jalan Segmen 2 


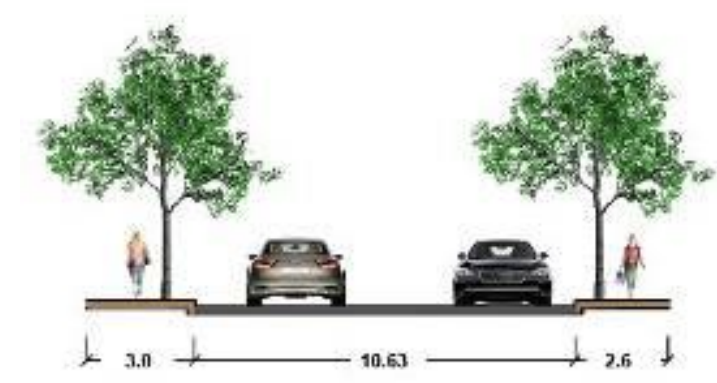

Potongan Jalan Segmen 3

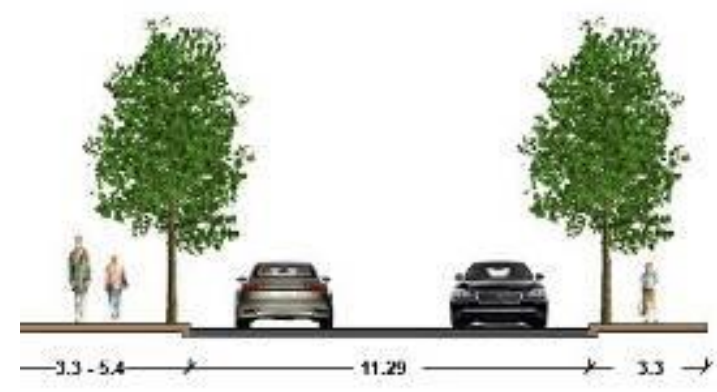

Potongan Jalan Segmen 5

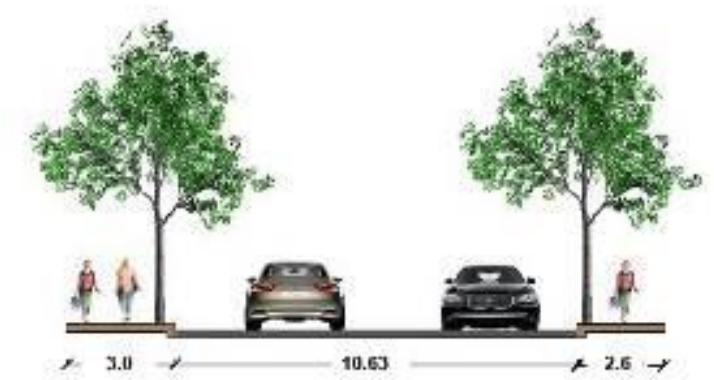

Potongan Jalan Segmen 7

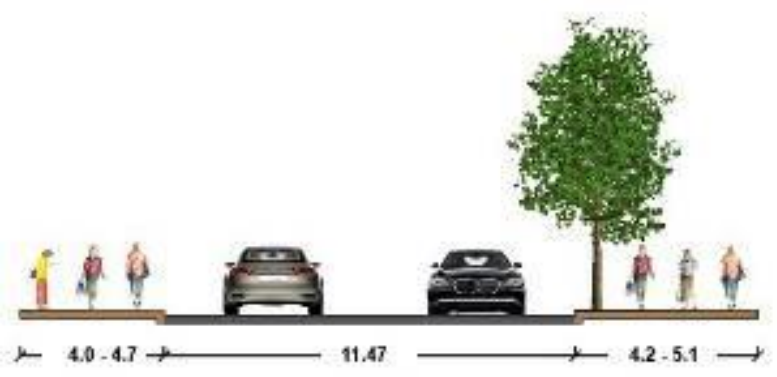

Potongan Jalan Segmen 4

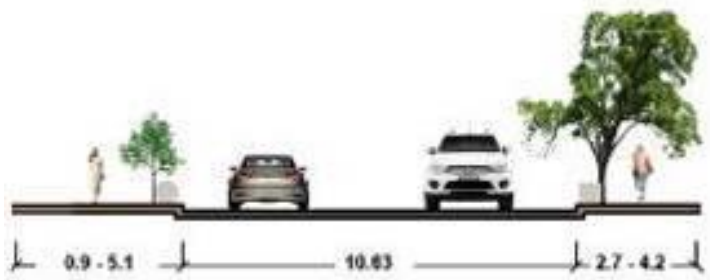

Potongan Jalan Segmen 6

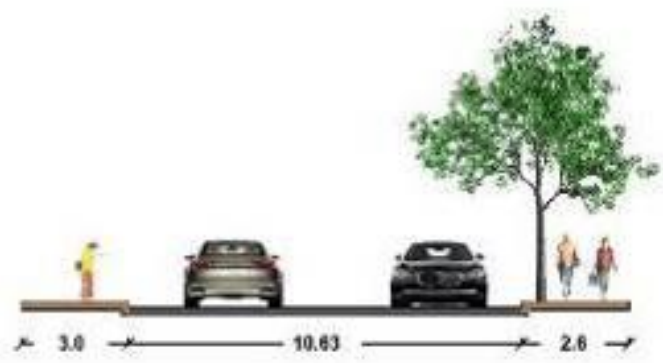

Potongan Jalan Segmen 8

Peraturan Menteri Pekerjaan Umum Nomor: 03/PRT/M/2014 pasal 2 ayat 2 menyebutkan bahwa Peraturan Menteri dibuat dengan tujuan untuk mewujudkan jaringan pedestrian di kawasan perkotaan yang aman, nyaman, dan manusiawi sehingga mendorong masyarakat untuk berjalan kaki dan menggunakan transportasi publik. Ketentuan dan tata cara perencanaan, penyediaan, pemanfaatan prasarana dan sarana jaringan pedestrian terdapat didalam peraturan menteri tersebut diatas, sehingga semua perencanaan sudah seharusnya mengacu terhadap peraturan menteri tersebut.

Untuk mengetahui apakah pedestrian sudah memenuhi standar perencanaan maka data-data yang sudah dikumpulkan dikaji menurut variabel penelitian yang sudah dibuat berdasarkan Peraturan Menteri Pekerjaan Umum. Analisa ditampilkan dalam bentuk tabel untuk memudahkan kajian. (Tabel 3. Kajian Ukuran, Peletakan dan Material) 
Tabel 3. Kajian Ukuran, Peletakan dan Material

VARIABEL

Menurut PERMENPU

03/PRT/M /2014, DPU 1998

dan Time Saver

\section{DATA PENGUKURAN TIAP SEGMEN}

\begin{tabular}{cccccccc}
\hline 1 & 2 & 3 & 4 & 5 & 6 & 7 & 8 \\
$(296 \mathrm{~m})$ & $(233 \mathrm{~m})$ & $(452 \mathrm{~m})$ & $(511 \mathrm{M})$ & $(278 \mathrm{~m})$ & $(570 \mathrm{~m})$ & $(252 \mathrm{~m})$ & $(350 \mathrm{~m})$
\end{tabular}

\section{SIRKULASI}

Lebar bersih min. 0

$\begin{array}{ll}2.5 \mathrm{~m} \mathrm{~s} / \mathrm{d} & 4.5 \mathrm{~m} \mathrm{~s} / \mathrm{d} \\ 3.6 \mathrm{~m} & 5.5 \mathrm{~m}\end{array}$

\section{$2.6 \mathrm{~m}$}

$4 \mathrm{~m} \quad \mathrm{~s} / \mathrm{d} \quad 3.3 \mathrm{~m}$

$\mathrm{s} / \mathrm{d}$

$5.1 \mathrm{~m}$

$\mathrm{s} / \mathrm{d}$

$0.9 \mathrm{~m}$

$2.4 \mathrm{~m}$

$\mathrm{s} / \mathrm{d}$

$\mathrm{s} / \mathrm{d}$

$6 \mathrm{~m}$

$5.4 \mathrm{~m}$

$5.1 \mathrm{~m}$

$3 \mathrm{~m}$

Lebar min. Difabel $1.4 \mathrm{~m}$

$3.9 \mathrm{~m}$

$3.4 \mathrm{~m}$

$2.7 \mathrm{~m}$

$0.9 \mathrm{~m}$

$1.8 \mathrm{~m}$

$2.4 \mathrm{~m}$

$1.5 \mathrm{~m}$

\begin{tabular}{|c|c|c|c|c|c|c|c|c|}
\hline Kelandaian & $8 \%$ & $8 \%$ & $8 \%$ & $8 \%$ & $8 \%$ & $8 \%$ & $8 \%$ & $8 \%$ \\
\hline $\begin{array}{l}\text { Tinggi maks. dari jalur } \\
\text { kendaraan }\end{array}$ & $15 \mathrm{~cm}$ & $15 \mathrm{~cm}$ & $15 \mathrm{~cm}$ & $15 \mathrm{~cm}$ & $15 \mathrm{~cm}$ & $\begin{array}{l}15 \mathrm{~cm} \\
\text { dan } \\
45 \mathrm{~cm}\end{array}$ & $15 \mathrm{~cm}$ & $15 \mathrm{~cm}$ \\
\hline $\begin{array}{l}\text { Ukuran ubin pengarah } \\
30 \times 30\end{array}$ & $30 \times 30$ & $30 \times 30$ & $30 \times 30$ & $30 \times 30$ & $30 \times 30$ & $30 \times 30$ & $30 \times 30$ & $30 \times 30$ \\
\hline $\begin{array}{l}\text { Material tahan cuaca, } \\
\text { tidak licin dan mudah } \\
\text { perawatan }\end{array}$ & $\begin{array}{l}\text { Granit } \\
\text { Bakar }\end{array}$ & $\begin{array}{l}\text { Granit } \\
\text { Bakar }\end{array}$ & $\begin{array}{l}\text { Granit } \\
\text { Bakar }\end{array}$ & $\begin{array}{l}\text { Granit } \\
\text { Bakar }\end{array}$ & $\begin{array}{l}\text { Granit } \\
\text { Bakar }\end{array}$ & $\begin{array}{l}\text { Granit } \\
\text { Bakar }\end{array}$ & $\begin{array}{l}\text { Granit } \\
\text { Bakar }\end{array}$ & $\begin{array}{l}\text { Granit } \\
\text { Bakar }\end{array}$ \\
\hline \multicolumn{9}{|l|}{$\begin{array}{l}\text { LAMPU } \\
\text { PENERANGAN }\end{array}$} \\
\hline Tinggi maks $4 \mathrm{~m}$ & $4 m$ & $4 \mathrm{~m}$ & $4 m$ & $4 \mathrm{~m}$ & $4 m$ & $4 \mathrm{~m}$ & $\begin{array}{l}\text { Belum } \\
\text { ada }\end{array}$ & $\begin{array}{l}\text { Belum } \\
\text { ada }\end{array}$ \\
\hline Peletakan setiap $10 \mathrm{~m}$ & $\begin{array}{l}27.6- \\
31.8 \mathrm{~m}\end{array}$ & $24-40 \mathrm{~m}$ & $24-40 \mathrm{~m}$ & $30 \mathrm{~m}$ & $30 \mathrm{~m}$ & $30 \mathrm{~m}$ & $\begin{array}{l}\text { Belum } \\
\text { ada }\end{array}$ & $\begin{array}{l}\text { Belum } \\
\text { ada }\end{array}$ \\
\hline $\begin{array}{l}\text { Material yang } \\
\text { disarankan metal dan } \\
\text { beton cetak }\end{array}$ & Besi & Besi & Besi & Besi & Besi & Besi & $\begin{array}{l}\text { Belum } \\
\text { ada }\end{array}$ & $\begin{array}{l}\text { Belum } \\
\text { ada }\end{array}$ \\
\hline \multicolumn{9}{|l|}{ RAMBU JALAN } \\
\hline $\begin{array}{l}\begin{array}{l}\text { Peletakan di titik } \\
\text { interaksi } \\
\text { pesial, } \\
\text { pedestrian jalur padat }\end{array} \\
\end{array}$ & ya & ya & ya & ya & ya & ya & ya & ya \\
\hline $\begin{array}{l}\text { Material tidak } \\
\text { menimbulkan silau }\end{array}$ & $\begin{array}{l}\text { Cat } \\
\text { standar }\end{array}$ & $\begin{array}{l}\text { Cat } \\
\text { standar }\end{array}$ & $\begin{array}{l}\text { Cat } \\
\text { standar }\end{array}$ & $\begin{array}{l}\text { Cat } \\
\text { standar }\end{array}$ & $\begin{array}{l}\text { Cat } \\
\text { standar }\end{array}$ & $\begin{array}{l}\text { Cat } \\
\text { standar }\end{array}$ & $\begin{array}{l}\text { Cat } \\
\text { standar }\end{array}$ & $\begin{array}{l}\text { Cat } \\
\text { standar }\end{array}$ \\
\hline \multicolumn{9}{|c|}{$\begin{array}{l}\text { PENYEBERANGAN } \\
\text { (Zebra Cross) }\end{array}$} \\
\hline Lebar $0.3 \mathrm{~m}$ & $0.3 \mathrm{~m}$ & $0.3 \mathrm{~m}$ & $0.3 \mathrm{~m}$ & $0.3 \mathrm{~m}$ & $0.3 \mathrm{~m}$ & $0.3 \mathrm{~m}$ & $0.3 \mathrm{~m}$ & $0.3 \mathrm{~m}$ \\
\hline Panjang min $2.5 \mathrm{~m}$ & $2.5 \mathrm{~m}$ & $2.5 \mathrm{~m}$ & $2.5 \mathrm{~m}$ & $2.5 \mathrm{~m}$ & $2.5 \mathrm{~m}$ & $2.5 \mathrm{~m}$ & $2.5 \mathrm{~m}$ & $2.5 \mathrm{~m}$ \\
\hline Celah garis $0.3-0.6 \mathrm{~m}$ & $0.3 \mathrm{~m}$ & $0.3 \mathrm{~m}$ & $0.3 \mathrm{~m}$ & $0.3 \mathrm{~m}$ & $0.3 \mathrm{~m}$ & $0.3 \mathrm{~m}$ & $0.3 \mathrm{~m}$ & $0.3 \mathrm{~m}$ \\
\hline $\begin{array}{l}\text { Peletakan di setiap } \\
\text { simpang }\end{array}$ & ya & ya & ya & ya & ya & ya & ya & ya \\
\hline \multicolumn{9}{|l|}{ TEMPAT DUDUK } \\
\hline Lebar $0.4-0.5 \mathrm{~m}$ & $0.33 \mathrm{~m}$ & $0.33 \mathrm{~m}$ & $0.33 \mathrm{~m}$ & $0.33 \mathrm{~m}$ & $0.33 \mathrm{~m}$ & $0.33 \mathrm{~m}$ & $\begin{array}{l}\text { Belum } \\
\text { ada }\end{array}$ & $\begin{array}{l}\text { Belum } \\
\text { ada }\end{array}$ \\
\hline Panjang $1.5 \mathrm{~m}$ & $1.4 \mathrm{~m}$ & $1.4 \mathrm{~m}$ & $1.4 \mathrm{~m}$ & $1.4 \mathrm{~m}$ & $1.4 \mathrm{~m}$ & $1.4 \mathrm{~m}$ & $\begin{array}{l}\text { Belum } \\
\text { ada }\end{array}$ & $\begin{array}{l}\text { Belum } \\
\text { ada }\end{array}$ \\
\hline Peletakan setiap $10 \mathrm{~m}$ & $>10$ & $6.6 \mathrm{~m}$ & $\begin{array}{l}6.6- \\
12 \mathrm{~m}\end{array}$ & $6.6-10 \mathrm{~m}$ & $6.6 \mathrm{~m}$ & $6.6 \mathrm{~m}$ & $\begin{array}{l}\text { Belum } \\
\text { ada }\end{array}$ & $\begin{array}{l}\text { Belum } \\
\text { ada }\end{array}$ \\
\hline $\begin{array}{lr}\text { Material yang } \\
\text { dianjurkan metal atau }\end{array}$ & $\begin{array}{l}\text { Besi cor } \\
\text { dan }\end{array}$ & $\begin{array}{l}\text { Besi cor } \\
\text { dan kayu }\end{array}$ & $\begin{array}{l}\text { Besi } \\
\text { cor dan }\end{array}$ & $\begin{array}{l}\text { Besi cor } \\
\text { dan kayu }\end{array}$ & $\begin{array}{l}\text { Besi cor } \\
\text { dan }\end{array}$ & $\begin{array}{l}\text { Besi cor } \\
\text { dan }\end{array}$ & $\begin{array}{l}\text { Belum } \\
\text { ada }\end{array}$ & $\begin{array}{l}\text { Belum } \\
\text { ada }\end{array}$ \\
\hline
\end{tabular}




\begin{tabular}{|c|c|c|c|c|c|c|c|c|}
\hline beton cetak & kayu & & kayu & & kayu & kayu & & \\
\hline \multicolumn{9}{|l|}{ TEMPAT SAMPAH } \\
\hline $\begin{array}{l}\text { Jarak antar tempat } \\
\text { sampah } 20 \text { meter }\end{array}$ & $>20 \mathrm{~m}$ & $20 \mathrm{~m}$ & $10-40 \mathrm{~m}$ & $10-40 \mathrm{~m}$ & $10-30 \mathrm{~m}$ & $10-30 \mathrm{~m}$ & $\begin{array}{l}\text { Belum } \\
\text { ada }\end{array}$ & $\begin{array}{l}\text { Belum } \\
\text { ada }\end{array}$ \\
\hline $\begin{array}{l}\text { Material yang } \\
\text { dianjurkan metal dan } \\
\text { beton cetak }\end{array}$ & $\begin{array}{l}\text { Kayu, } \\
\text { besi dan } \\
\text { plastik }\end{array}$ & $\begin{array}{l}\text { Kayu, } \\
\text { besi dan } \\
\text { plastik }\end{array}$ & $\begin{array}{l}\text { Kayu, } \\
\text { besi } \\
\text { dan } \\
\text { plastik }\end{array}$ & $\begin{array}{l}\text { Kayu, } \\
\text { besi dan } \\
\text { plastik }\end{array}$ & $\begin{array}{l}\text { Kayu, } \\
\text { besi dan } \\
\text { plastik }\end{array}$ & $\begin{array}{l}\text { Kayu, } \\
\text { besi dan } \\
\text { plastik }\end{array}$ & $\begin{array}{l}\text { Belum } \\
\text { ada }\end{array}$ & $\begin{array}{l}\text { Belum } \\
\text { ada }\end{array}$ \\
\hline \multicolumn{9}{|l|}{ HALTE } \\
\hline $\begin{array}{l}\text { Lapak tunggu pada } \\
\text { radius } 300 \text { meter }\end{array}$ & $\begin{array}{l}\text { Jumlah } \\
1 \text { buah }\end{array}$ & $\begin{array}{l}\text { Jumlah } \\
1 \text { buah }\end{array}$ & $\begin{array}{l}\text { Belum } \\
\text { ada }\end{array}$ & $\begin{array}{l}\text { Belum } \\
\text { ada }\end{array}$ & $\begin{array}{l}\text { Jumlah } \\
1 \text { buah }\end{array}$ & $\begin{array}{l}\text { Belum } \\
\text { ada }\end{array}$ & $\begin{array}{l}\text { Belum } \\
\text { ada }\end{array}$ & $\begin{array}{l}\text { Belum } \\
\text { ada }\end{array}$ \\
\hline $\begin{array}{l}\text { Material yang } \\
\text { dianjurkan metal dan } \\
\text { beton cetak. }\end{array}$ & $\begin{array}{l}\mathrm{ACP}, \\
\text { keramik }\end{array}$ & $\begin{array}{l}\mathrm{ACP}, \\
\text { keramik }\end{array}$ & & & $\begin{array}{l}\mathrm{ACP}, \\
\text { keramik }\end{array}$ & & & \\
\hline \multicolumn{9}{|l|}{ VEGETASI } \\
\hline $\begin{array}{l}\text { Percabangan } 2 \mathrm{~m} \text { dari } \\
\text { tanah }\end{array}$ & $>2.5 \mathrm{~m}$ & $>2.5 \mathrm{~m}$ & $>2.5 \mathrm{~m}$ & $>2.5 \mathrm{~m}$ & $>2.5 \mathrm{~m}$ & $>2.5 \mathrm{~m}$ & $>2.5 \mathrm{~m}$ & $>2.5 \mathrm{~m}$ \\
\hline $\begin{array}{ll}\begin{array}{l}\text { Ditanam } \\
\text { berbaris }\end{array} & \text { secara } \\
\end{array}$ & Ya & $\mathrm{Ya}$ & $\mathrm{Ya}$ & $\mathrm{Ya}$ & $\mathrm{Ya}$ & $\mathrm{Ya}$ & $\mathrm{Ya}$ & $\mathrm{Ya}$ \\
\hline $\begin{array}{ll}\text { Jenis: Kiara } & \text { Payung, } \\
\text { Tnajung, } & \text { Bungur, } \\
\text { Mahoni, } & \text { Angsana, } \\
\text { Akasia, } & \text { Bogenvil, } \\
\text { Teh-tehan } & \end{array}$ & Angsana & Mahoni & Mahoni & Angsana & Mahoni & Tanjung & Tanjung & Tanjung \\
\hline
\end{tabular}

\section{KESIMPULAN}

1. Elemen-elemen pedestrian

a. Elemen pedestrian terbuat dari material batu Granit Bakar sesuai dengan Teori Rubenstein bahwa material pedestrian sebaiknya paving, beton atau batu.

b. Elemen-elemen pendukung yang terdapat di koridor, yaitu terdapatnya lampu penerangan, rambu-rambu jalan, bollard, bangku,shelter dan tanaman peneduh sesuai dengan Teori Rubenstein tentang elemen-elemen pendukung jalur pedestrian.

2. Ukuran, peletakan dan material

a. Sirkulasi; ukuran lebar bersih minimal $1.5 \mathrm{~m}$ untuk difabel, hampir semua sudah memenuhi, kecuali segmen 1 ada yang selebar $1.4 \mathrm{~m}$ dan segmen 6 selebar $0.9 \mathrm{~m}$. Ketinggian pedestrian maksimal $20 \mathrm{~cm}$ dari jalur kendaraan sudah memenuhi, kecuali di segmen 6 ada ketinggian trotoar $45 \mathrm{~cm}$. Kelandaian $<8 \%$ sudah memenuhi di setiap segmen. Ukuran ubin pengarah 30x30 dan material sudah memenuhi di setiap segmen.

b. Lampu pedestrian; ukuran ketinggian $4 \mathrm{~m}$ dan material metal sudah memenuhi kecuali di segmen 7 dan 8 , ketika survey dilakukan belum terpasang. Peletakan maksimal setiap $10 \mathrm{~m}$ belum memenuhi standar di semua segmen (rata-rata 30m).

c. Rambu jalan tidak menimbulkan silau sudah memenuhi di setiap segmen.

d. Penyeberangan (zebra cross), sudah memenuhi standar di setiap segmen.

e. Tempat duduk, dimensi dan ukuran sudah memenuhi standar kecuali segmen 7 dan segmen 8 , belum terpasang. Pola peletakan, jarak antar tempat duduk, sudah memenuhi standar di segmen 2, 5 dan 6, belum memenuhi standar di segmen 1, 3, 4, 7 dan 8. Material tidak sesuai standar yang disarankan.

f. Tempat sampah; jarak peletakan yang memenuhi standar hanya di segmen 2. Material tidak sesuai standar yang disarankan. 
g. Halte, peletakan, jarak antar halte, sudah memenuhi standar di segmen 1, 2 dan 5, belum memenuhi standar di segmen 3, 4, 6, 7 dan 8

h. Vegetasi Peneduh sudah memenuhi standar di semua segmen baik ukuran maupun jenis yang disarankan.

Jadi dapat disimpulkan bahwa Koridor Jl. R.E. Martadinata sudah memiliki kelengkapan elemen material dan pendukung jalur pedestrian dan sebagian besar sudah memenuhi standar perencanaan yang dikeluarkan oleh Pemerintah

\section{DAFTAR PUSTAKA}

[1] Carr, Stephen. 1992. Public Space. Cambridge: The Press Syndicate of The University of Cabridge Press

[2] Siregar, Johannes Parlidungan. Perwujudan Ruang Publik Perkotaan. http://johannes.lecture.ub.ac.id/2012/05/perwujudan-ruang-publik-perkotaan (diakses 12 November 2016)

[3] Sukawi.Trotoar oh trotoar. Jurnal Arsitektur Fakultas Teknik Undip. http://eprints.undip.ac.id/1465/ (diakses 12 November 2016)

[4] Nooriman,Qudrah. Studi Kualitas Jalur Pedestrian di Jalan DR.Mansyur Medan Ditinjau dari Faktor Fisik. http://repository.usu.ac.id (diakses 15 Oktober 2016).

[5] Syoufa, Ade. Tinjauan Tingkat Keamanan dan Kenyamanan Pedestrian pada Desain Trotoar Jalan Margonda Raya Depok dengan Jalan Padjajaran Bogor. Jurnal Desain Konstruksi Volume 16 No.2. 2017. Jurnal Teknik Arsitektur. Universitas Gunadarma.

[6] Carmona, et al. 2008. Public space: the management dimension. Routledge, Taylor\&Francis group. New York, USA.

[7] Rubenstein, H.M.1992. Pedestrian Malls, Streetscapes, and Urban Spaces. New York: John Willey $\&$ Sons Inc

[8] Peraturan Menteri Pekerjaan Umum nomer 03/PRT/M/2014 